\title{
THE INFLUENCE OF SOCIAL MEDIA COMMUNICATION ON CONSUMER'S ATTITUDES AND BEHAVIORAL INTENTIONS CONCERNING BRAND-SPONSORED EVENTS
}

\author{
BRUNO SCHIVINSKI, $*$ DANIELA LANGARO, $\dagger$ AND CHRISTINA SHAW $\$$ \\ *Department of Management, Birkbeck, University of London, London, UK \\ $\dagger$ Department of Marketing and Operations, Instituto Universitário de Lisboa (ISCTE-IUL), \\ Lisbon, Portugal \\ $\$$ Nottingham Business School, Nottingham Trent University, Nottingham, UK
}

\begin{abstract}
Social media communication was suggested to influence consumers on their decision process of participating in events. Despite the relevance of evaluating this proposition, the effects of social media brand-related communications on event attendance were not yet validated. To address this literature gap, it was evaluated whether firm-created and user-generated social media brand-related content influenced consumers' attitudes and, consequently, their intentions to participate in brand-sponsored events. Additionally, the mediating role of consumers' attitudes towards the brand and the event was examined. An online survey $(n=307)$ was implemented and results were analyzed with structural equation modeling (SEM). The findings contribute to managers and scholars in the field of events marketing in general and brand-sponsored events in specific, by means of proposing and validating a model that confirms (1) the effects of firm-created social media (SM) brand-related content on brand attitude, (2) the influence of user-generated SM brand-related content on both brand and event attitudes, (3) the impact of brand attitude on event attitude, (4) the influence of event attitude on the consumers' intentions to participate; and (5) identifies different arrays revealing how consumers' attitudes towards the brand and the event mediate the relationship between SM communications on consumers' behavioral intentions, while distinguishing the type of SM brand-related content source.
\end{abstract}

\section{Key words: Social media; Event marketing; Brand attitude; Event attitude;} Event participation

Address correspondence to Bruno Schivinski, Ph.D., at his current affiliation: Senior Lecturer in Advertising, School of Media and Communication, RMIT University, 124 La Trobe St., Melbourne, VIC 3000, Australia. E-mail: bruno.schivinski@gmail.com 


\section{Introduction}

Social media platforms have been increasingly adopted by marketers who envision reaching large audiences with their brands. Currently, social media (hereafter SM) users represent more than $70 \%$ of the total online population (Hootsuite, 2017). Among the largest SM platforms are Facebook, Instagram, Twitter, and YouTube, which account for more than 2.5 billion users (Hootsuite, 2017; socialbakers, 2017). Facebook is the most representative one with more than 1.3 billion active daily users, who stay connected in average for 20 mins and access the platform at least eight times a day (Hootsuite, 2017). In response to that trend, brands have launched their own brand pages and started communicating directly with consumers. As a result, more than 70 million brand pages have been launched.

As brands join SM platforms with their pages, they engage in an opened online dialog with consumers (Berthon, Pitt, Plangger, \& Shapiro, 2012). Firms use $\mathrm{SM}$ as a communication channel to enlarge and reinforce their customer base, while influencing consumers' perceptions about brands and product offerings (Schivinski \& Dabrowski, 2016). Consumers, on the other hand, gain increased access to brands and are incentivized to consume, contribute, and create SM brandrelated content (Muntinga, Smit, \& Moorman, 2012; Schivinski, Christodoulides, \& Dabrowski, 2016).

The effects of brands using SM as a communication channel have been proven to positively impact various cognitive and emotional brand dimensions, as for instance brand awareness (Langaro, Rita, \& de Fátima Salgueiro, 2015; Schivinski \& Dabrowski, 2015; Xiang \& Gretzel, 2010), brand attitude (Langaro et al., 2015; Schivinski \& Dabrowski, 2015), brand trust (Brodie, Ilic, Juric, \& Hollebeek, 2013; Laroche, Habibi, Richard, \& Sankaranarayanan, 2012), brand commitment, and emotional bonding (Brodie et al., 2013; Filo, Lock, \& Karg, 2015; Turri \& Smith, 2013). Research has also investigated the effects of SM communication on behavioral dimensions such as purchase intentions (Hutter, Hautz, Dennhardt, \& Füller, 2013; Kim \& Kim, 2004), brand loyalty (Brodie et al., 2013; Jahn \& Kunz, 2012; Laroche et al., 2012), and word of mouth (Hutter et al., 2013; Wallace, Buil, \& Chernatony, 2014).

The positive influences of SM communication were validated across different product categories (Hutter et al., 2013; Langaro et al., 2015; Schivinski \& Dabrowski, 2016) and service contexts, as for instance in tourism (Kim \& Kim, 2004; Leung, Law, van Hoof, \& Buhalis, 2013; Xiang \& Gretzel, 2010), sports (Filo et al., 2015; Witkemper, Lim, \& Waldburger, 2012), and events (Berthon et al., 2012; Sneath, Finney, \& Close, 2005; Vanden Bergh, Lee, Quilliam, \& Hove, 2011; Wohlfeil \& Whelan, 2006; Wood, 2009; Zarantonello \& Schmitt, 2013). In the specific context of events marketing, previous studies have focused on evaluating the effects of SM in coproducing and cocreating the event experience itself, in terms of generating enhanced experiences while promoting users participation in SM platforms (Gyimóthy \& Larson, 2015; Hoksbergen \& Insch, 2016; Vanden Bergh et al., 2011). Other than enhancing the experience during the event, SM has also been suggested to influence consumers in the phase where they evaluate the event and decide their attendance (Hudson, Roth, Madden, \& Hudson, 2015). Therefore, SM communication can be acknowledged for influencing consumers on their decision process of participating in events. Despite the logical managerial and theoretical interest of validating this proposition, the effects of brand-related SM communications on event attendance have not yet been empirically investigated, therefore portraying an important literature gap and supporting the need of empirical research.

To address the above-mentioned knowledge gap, the current study evaluates the effects of SM communications on consumers' attitudes and intentions to participate in events. More specifically, the study focuses on brand-sponsored events. Brand-sponsored events are defined as experiences initiated by the company designed with the specific objective of communicating brand messages to target audiences (Altschwager, Goodman, Conduit, \& Habel, 2015; Wohlfeil \& Whelan, 2006). The managerial enthusiasm around sponsored events is associated to the positive impact of generating multisensorial brand experiences while pursuing new strategies for brand differentiation (Altschwager et al., 2015; Wohlfeil \& Whelan, 2006; Zarantonello \& Schmitt, 2013). Along the last decade, brands have increasingly 
adopted sponsored events in their communication plans, with budgets allocated to events having more than doubled (Statista, 2017a). This level of enthusiasm is extended to social media with Facebook, for instance, having reported more than 47 million events being annually created, with more than 550 million users and thousands of brands involved.

In view of the existing gap in the literature and the relevance of brand-sponsored events, the current research introduces a conceptual model that evaluates whether social media, as a communication channel, positively influences consumers' attitudes towards brands and events, and subsequently their behavioral intentions towards participating in brand-sponsored events. While evaluating these effects, differences associated to the type of communication sources are considered, with firm-created and user-generated SM brand-related content being separately analyzed given their different nature, as highlighted in Schivinski and Dabrowski (2015, 2016). Moreover, to further understand how SM communication impacts consumers' behavioral intentions, the attitudes towards the brand and the event are analyzed for mediating effects. Although literature in social media supports that brand messages create and strengthen the consumers' perceptions of brands (Schivinski \& Dabrowski, 2016), it fails to explain the indirect effects of attitudes in this process. The mediating effects proposed find support in the literature of brand management and communications as consumers' attitudes are largely accepted for triggering conative responses (e.g., purchase intentions) (Pradhan, Duraipandian, \& Sethi, 2016).

In sum, to address the literature gaps described, two research objectives are proposed. The first envisions to understand whether firm-created and user-generated SM brand-related content directly influence consumers' attitudes, and if those consequently impact their behavioral intentions towards participating in a brand-sponsored event. The second investigates the mediating role of consumers' attitudes towards the brand and event on the relationship between SM brand-related communication and intention to participate in brand-sponsored events. The findings contribute to managers and scholars in the field of events marketing in general and brand-sponsored events in specific, by means of proposing and validating a model that confirms
(1) the effects of firm-created SM brand-related content on brand attitude, (2) the influence of usergenerated SM brand-related content on both brand and event attitudes, (3) the impact of brand attitude on event attitude, (4) the influence of event attitude on the consumers' intentions to participate; and identifies (5) different arrays revealing how consumers' attitudes towards the brand and the event mediate the relationship between SM communications on consumers' behavioral intentions, while distinguishing the type of SM brand-related content source (i.e., firm created vs. user generated).

\section{Conceptual Framework and} Hypotheses Development

\section{Social Media Brand-Related Communication}

On SM platforms both firms and users are involved in creating and disseminating brand-related content (Bambauer-Sachse \& Mangold, 2011). These two content sources are acknowledged for their different nature (Bruhn, Schnebelen, \& Schäfer, 2013; Schivinski \& Dabrowski, 2015, 2016). Some authors refer to firm-created SM content as a type of advertising (Bruhn, Schoenmueller, \& Schäfer, 2012) in the sense that it is integrated in the overall brand positioning and creative idea, and it is initiated by the brand. From the moment consumers start following brands on SM or have any previous online contact with the brand (and/or its products) they start receiving SM brand-related content. While exposed to firm-initiated SM communication, consumers enjoy brand-related content targeted at entertaining, sharing information, and promoting followers' self-expression and social interactions (de Vries, Peluso, Romani, Leeflang, \& Marcati, 2017; Shao, 2009). Therefore, firmcreated SM content is a platform targeted at captivating the customer's participation through consuming the contents that are shared (e.g., reading posts, viewing pictures), contributing with opinions (e.g., liking/disliking, commenting on posts), and/or creating new brand-related content (e.g., publishing posts with their own network of friends) (Langaro et al., 2015; Muntinga et al., 2012; Schivinski et al., 2016). In the current study, the concept of firmcreated SM brand-related content is approached as a form of advertising, and therefore hypothesized 
a priori in which consumers exposed to this type of communication are positively influenced in their intentions to participate in brand-sponsored events.

The second type of SM brand-related communication is also known in literature as user-generated content (UGC). UGC is characterized for being public and available over the Internet, for occurring outside users' professional routines and practices, and for being independent in the sense of not being controlled by firms (Organisation for Economic Co-operation and Development [OECD], 2007). When consumers involve brands in their stories, they often approach them from two different perspectives. Either consumers create content around themselves (user centered), using brands for supporting their own self representation, or they create content around brands (brand centered) (A. N. Smith, Fischer, \& Yongjian, 2012). In this perspective, brands assume a secondary role being used for the symbolic meanings they convey in consumers' self-expression (A. N. Smith et al., 2012). In the brand-centered perspective users create content in order to voice their opinions about the object of interest. Opinions may be positive, with users advocating in favor of brands, or negative, with users complaining. Previous studies have concluded that the valence of brand-related content is predominantly positive and significant in influencing behavioral responses (Chevalier \& Mayzlin, 2006; Cui, Lui, Chan, \& Joy, 2012; A. N. Smith et al., 2012). Most importantly, user-generated SM brandrelated content is perceived as trustworthy because it is not seen as traditional advertising and it is not controlled by the brand (Christodoulides, Jevons, $\&$ Bonhomme, 2012). In view of previous findings, the current research focuses on the positive aspects of UGC and hypothesizes that consumers, which are exposed to this type of SM communication, are positively influenced in their intentions to participate in brand-sponsored events.

\section{Effects of SM Brand-Related Communication on Consumer's Attitudes}

Research on attitudes finds its origins in the area of behavioral psychology with scholars evaluating attitudes for their influence on mediating the effects between individuals' stimuli, perceptions, and actual behavior (R. E. Smith \& Swinyard, 1983). The psychological roots of attitudes found logical fit in the area of consumer behavior, with various studies being dedicated to understanding the role of attitudes on the consumer decisionmaking process (Blackwell, Miniard, \& Engel, 2001). The main reasoning underlying those studies is that attitudes integrate an important role in consumers' persuasion, with positive attitudes producing changes in purchase-related behavior (Fazio, Powell, \& Williams, 1989).

Previous studies in the area of marketing have accepted the definition that brand attitude is the "consumer's overall evaluation of a brand" (Olson $\&$ Mitchell, 1981). Brand attitude evolves from the associations consumers have with brands, requiring an additional level of elaboration, with individuals generating beliefs and judgments regarding the brand attributes and benefits learned (Keller, 1993; Spears \& Singh, 2004). Due to their synthetic and abstract nature (i.e., beliefs and judgments), brand attitudes are more accessible in memory than the attributes and benefits that underlie a brand (Keller, 1993). The same cognitive mechanism could be transposed to how consumers perceive services, and even more specific to events (Gwinner, 1997). Therefore, in the current study event attitude is defined as the enduring evaluative perceptions of an event (Cohen, 2001; Gwinner, 1997), being formed through associations held in the consumer's memory (Keller, 1993). While operationalizing the construct, the current study focuses on evaluating the attitudes that the brand endows to an event that it sponsors.

In the SM context, research on the consumer's exposure to SM brand-related communication was shown to positively impact perceptions of brands (Bruhn et al., 2012; Schivinski \& Dabrowski, 2015, 2016). Although SM brand-related communication appears to influence consumers' attitudes, its investigation is still warranted given that the literature on SM brand-related communication is scattered (Moro, Rita, \& Vala, 2016), and varies across industries and sources (Bruhn et al., 2012; Schivinski \& Dabrowski, 2015, 2016), contexts (Ibrahim, Wang, \& Bourne, 2017), and business orientations (Huotari, Ulkuniemi, Saraniemi, \& Mäläskä, 2015). To advance research on the effects of SM brandrelated communication on consumers' attitudes and 
responses, previous authors have suggested that further research on different contexts to investigate its effectiveness and managerial feasibility is necessary (Kumar, Bezawada, Rishika, Janakiraman, \& Kannan, 2016; Schivinski et al., 2016).

A study by Bruhn et al. (2012) revealed that he impact of SM brand-related communication on consumers' perceptions of brands (measured as brand associations and brand image) varies across the SM source type. More specifically, their study informed that firm-created SM communication had a greater influence on consumers' mindsets than user-generated communication. Contrarily, in the study of Schivinski and Dąbrowski (2016), findings demonstrated that user-generated SM communication was a better driver of consumers' perceptions of brands, measured as brand equity and brand attitude, when compared to firm-created communication. Further support to the effectiveness of usergenerated over firm-created SM communication was evidenced on its influence on brand awareness, associations, quality, and loyalty (Schivinski \& Dabrowski, 2015).

Despite the fact that (1) previous studies investigating the consumers' perceptions of brands on SM focused on selected product brands and industries and (2) the variation of findings discriminate which type of SM brand-related communication is more effective in terms of creating and shaping consumers' perceptions, there is evidence that when brands communicate by means of SM, they aim to impact consumers' perceived attributes and benefits towards brands. While doing that, attitudes are reinforced in their level of strength, uniqueness, or favorability. The positive effects of SM on attitudes may be interpreted in view of the fact that SM brand-related content created by both firms and peers are aimed at generating positive and gratifying experiences. Hence, SM communications convey functional, emotional, social, and individual benefits (Jahn \& Kunz, 2012; Shao, 2009; Zhang, Sung, \& Lee, 2010), which are experienced by the consumer, while being exposed to SM brand-related content, indifferently if firm created or user generated. In view of these effects it is expected that when users hold positive evaluations of the content they are exposed to, positive effects on brand attitude occur. The following hypotheses summarize the arguments above:
H1: Consumers' positive evaluations of firmcreated (H1a) and user-generated (H1b). SM brand-related communication positively influences brand attitude.

Previous studies concluded that in the context of digital platforms, a consumer's positive experience regarding their interactions contributes to generate a sense of enthusiasm and positivity towards other initiatives promoted by the brand (Bagozzi \& Dholakia, 2006). Likewise, it can be expected that when users hold positive evaluations regarding SM brand-related content that this will influence their attitudes towards events sponsored by the brand.

Moreover, while exposed to firm-created content consumers learn about brand-sponsored events, which are presented with the use of engaging language, aimed at generating positive attitudes towards the event and, in some cases, allowing users to see who will attend the event (e.g., Facebook Events) (Bogaert, Ballings, \& Van Den Poel, 2016). The positive effects expected are stated in the following hypotheses:

H2: Consumers' positive evaluations of firmcreated (H2a) and user-generated (H2b). SM brand-related communication positively influences event attitude.

\section{Effects of Brand Attitude on Event Attitude}

The literature in branding introduces the concept of secondary brand associations, referring to the mechanism of image transfer that takes place between parties as a result of their joint marketing efforts (Keller \& Lehmann, 2003; Peter \& Olson, 2009; Ruth, Ruth, Simonin, \& Simonin, 2003). These effects find support in the process of associative learning (Till \& Nowak, 2000) according to which individuals may learn about a stimulus (e.g., a brand) by means of associating it with another object. In the specific context of brand-sponsored events, the logic is that when firms associate their image with a certain type of event, transfer of associations from the event to the brand occur (Bloom, Hoeffler, Keller, \& Meza, 2006; Hoeffler \& Keller, 2002).

Secondary associations in the context of events marketing and sponsorship are most often analyzed from the perspective of the sponsor and focus on 
the brand image being transferred from the event to the sponsoring brand (Gwinner, 1997; Simonin \& Ruth, 1998). However, secondary associations occur both ways with brand associations and attitudes towards the sponsoring brand also being transferred to the event itself (Ruth et al., 2003). This perspective is adopted in the current research with transfer of positive evaluations being expected to occur from the brand itself to the brand-sponsored event, as proposed in the following hypothesis:

H3: Brand attitude has a positive effect on brand event attitude.

\section{Effects of Consumers 'Attitudes on Users' \\ Intentions to Participate in a \\ Brand-Sponsored Event}

The positive relationship between attitude and behavior is extensively documented in the marketing literature (Fazio et al., 1989; Ryan \& Bonfield, 1975; R. E. Smith \& Swinyard, 1983), finding support on the reasoning that consumers tend to behave consistently with their personal judgment (R. E. Smith \& Swinyard, 1983). According to that, consumers elaborate behavioral intentions from the objects towards which they hold positive evaluations (Brown \& Stayman, 1992; Michelini, Iasevoli, \& Theodoraki, 2017).

Research evidences that the effects of consumers' attitudes extend beyond intentional purchase behavior (Jaakkola \& Alexander, 2014), being proposed for influencing individuals in a broad scope of nontransactional brand-related behaviors (Jaakkola \& Alexander, 2014; van Doorn et al., 2010). Such behaviors include, for instance, the consumers' intention to participate in programs, activities, and events organized by the brand (Filo, Funk, \& Hornby, 2009; Vivek, Beatty, Dalela, \& Morgan, 2014; Vivek, Beatty, \& Morgan, 2012).

Despite the above-mentioned evidence, previous studies have mainly focused on evaluating event attendance as a consequence of consumers' motivational factors (Hall, O'Mahony, \& Vieceli, 2010; Hixson, Mccabe, \& Brown, 2011; Wohlfeil \& Whelan, 2006) and identification with the event promoter (e.g., football team) (Mohan \& Thomas, 2012). The few studies that explored consumers' attitudes as an antecedent of event attendance failed to consider the SM context (Filo et al., 2009; Prayag, Hosany, Nunkoo, \& Alders, 2013). The current research extends event marketing literature by arguing that consumers' positive attitudes, both towards the brand and event, should influence their intentions to participate in a brand-sponsored event. The following hypotheses summarize the above-mentioned arguments:

H4: Brand attitude has a positive effect on consumers' intentions to participate in a brandsponsored event.

H5: Event attitude has a positive effect on consumers' intentions to participate in a brandsponsored event.

\section{Mediating Effects of Consumers'Attitudes}

The relationship between SM brand-related communication and consumers' intentions to attend brand-sponsored events are expected to be mediated by brand and event attitudes. Hence, the consumers' behavioral responses exerted by SM brandrelated communication should increase/decrease according to levels of attitudes. This process is supported on rationale of attitude-behavior consistency and based on the Theory of Reasoned Action (TRA) (Ajzen \& Fishbein, 1980; Fishbein \& Ajzen, 1975). TRA states that individuals behave in accordance to attitudinal and normative anteceding components (Shimp \& Kavas, 1984). In the context of tourism, leisure, and events, TRA is successfully used to explain consumers' intentional behaviors (Han, Hsu, \& Sheu, 2010; Prayag et al., 2013; Quintal, Lee, \& Soutar, 2010). In the current study the attitudinal components of TRA are considered (as in Prayag, Hosany, Nunkoo, \& Alders, 2013), being suggested that consumers' attitudes towards an object (i.e., a brand and an event) influences their intentional behaviors (i.e., participating in a brand-sponsored event) (Conner \& Armitage, 1998; Shimp \& Kavas, 1984).

The strength of consumers' attitudes on intentional behavior is influenced by the accessibility of attitudes in the consumer's memory (Fazio et al., 1989). Accessibility is facilitated when attitudes towards a brand are activated and reinforced in memory by means of brand communications (R. E. Smith \& Swinyard, 1983). In line with TRA, the current research argues that the consumers' attitudes towards the brand and the event are expected 
to be activated and reinforced by means of their exposure to firm-created and user-generated SM brand-related communication. Hence, the consumers' perceptions are more accessible to being retrieved from memory when deciding on participating in a brand-sponsored event.

The directional hypotheses for this study are depicted in Figure 1. The specific mediational effects are articulated in the following hypotheses:

H6:Brand attitude (H6a) and event attitude (H6b) mediate the relationship between firm-created content and consumer's intentions to participate in brand events.

H7:Brand attitude (H7a) and event attitude $(\mathbf{H 7} \mathbf{b})$ mediate the relationship between user-generated content and consumers' intentions to participate in brand events.

H8: Brand attitude mediates the relationship between firm-created content (H8a), user-generated content $(\mathbf{H 8 b})$, and event attitude.

H9:Firm-created content (H9a) and user-generated content (H9b) initiate a mediational chain of brand attitude and event attitude influencing consumers' intentions to participate in brand events.

H10:Event attitude mediates the relationship between brand attitude and consumers' intentions to participate in brand events.

\section{Methods}

\section{Participants and Procedures}

Potential participants for this study were British consumers who follow event pages on major
SM channels (i.e., Facebook, Instagram, LinkedIn, and YouTube). To collect the data a standardized survey was created and hosted on Qualtrics (http:// www.qualtrics.com) and distributed through SM. The participants were briefly informed about the objective of the survey. The profile of the target sample was users of SM, aged 18 and above, who follow at least one brand on social media platforms. When an individual "likes" or "follows" a brand on SM they automatically receive content from the administrator of this page as well as others who also "like" or "follow" this SM page. Therefore, it is assumed that these individuals have access to content shared and posted by both the brand and other users.

To qualify this study, we followed the advice from Schivinski and Dabrowski (2016) for collecting data on SM platforms; hence, the brand SM pages needed to meet positive criteria referring to the frequency of SM communication (i.e., firm-created and user-generated content) with a minimum of a couple of posts per week; the firm-created content must be a form of advertising and generate positive brand associations; and the brand's SM page must also have over 500 followers. If the brand page did not meet these criteria, their data set was excluded from the analysis and evaluation.

A total of 421 responses were collected. As a characteristic of collecting online data, an estimation of how many people had access to the online survey is not accessible; therefore, calculations of the response rate for the study were omitted.

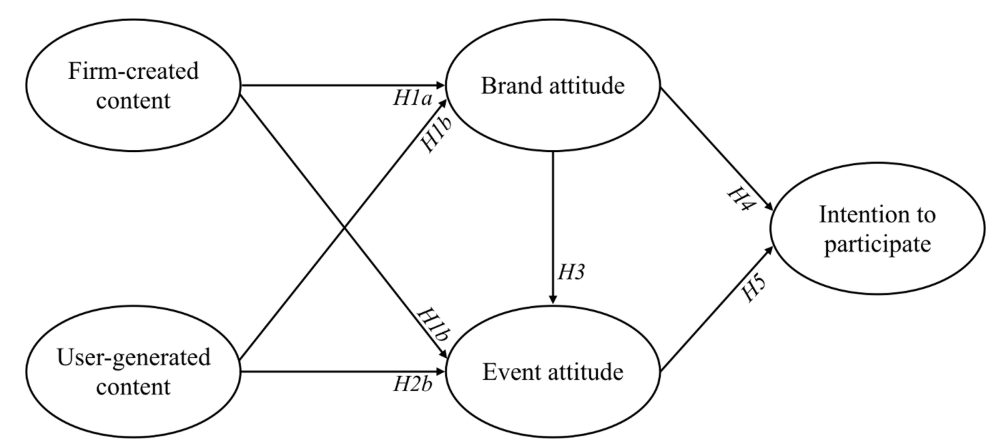

Figure 1. Conceptual model of SM brand-related content, attitudes, and intentional behavior. The conceptual model displays only the direct effects for reasons of visual clarity. 


\section{Measures}

Demographic data were collected on gender, age, and education. Data on SM usage and preference were collected by asking for participants' average weekly time spent on SM for leisure purposes, as well as the most frequent SM platform used. Data were collected on brands by asking participants to indicate a brand they followed on social media. Respondents later used the chosen brand throughout the survey to address the items.

For measuring SM communications, the latent variables of firm-created and user-generated SM content were measured using 4-item scales from Schivinski and Dabrowski (2016). Brand attitude and event attitude were measured using a threeitem scale adapted from G. Low and Lamb Jr. (2000) and Villarejo-Ramos and Sánchez-Franco (2005). Finally, consumer intentional behavior to participate in a brand event was measured using a three-item scale adopted from Lee, Xiong, and $\mathrm{Hu}$ (2012). All the items were measured with a 7-point Likert scale ranging from "strongly disagree" (1) to "strongly agree" (7). The complete list of items and descriptive statistics can be found in the Appendix.

\section{Data Management and Statistical Analysis}

Data management involved the following steps: a) inspecting the data for accuracy by checking for typos and if minimum and maximum scores were in range; $b$ ) cleaning the dataset by examining cases with missing values above the conventional threshold of $10 \%$ across the instruments; c) checking for univariate normality of all items using standard guidelines (i.e., skewness $>3$ and kurtosis $>9$ ) (Kline, 2011); d) screening for univariate outliers that scored greater than 3.29 standard deviations, as an absolute value, from the items' $z$-scores (Field, 2013); and e) screening for multivariate outliers using Mahalanobis distances and the critical value for each case based on the chi-square distribution values. This procedure yielded a final dataset of 307 valid cases that were eligible for subsequent analyses $(72.9 \%)$.

The statistical analysis included (1) descriptive analysis of the sample's characteristics; (2) confirmatory factor analysis of the main variables of the study; (3) path analysis with structural equation modeling (SEM) to test the hypotheses and conceptual framework; and (4) mediation analysis with SEM to compute the indirect effects of SM brand-related communication (both firm created and user generated) on the consumer's intention to participate in brand events through brand and event attitudes. Statistical analysis was performed using IBM SPSS Statistics 24 and Mplus 7.2.

\section{Results}

\section{Descriptive Statistics}

The demographic structure of the sample is as follows: the majority of respondents were female (58.4\%), 42.7\% were aged between 21 and 40, and $31 \%$ of the respondents declared to have at least some higher education. The majority of respondents $(88 \%)$ declared to use SM every day and the most accessed channels were Facebook (90.2\%), YouTube (61.1\%), and Instagram (35.3\%). The sociodemographic profile of the sample partly matches that of members of the British population who use SM frequently (Statista, 2017b). In total, 83 brands such as Adidas, $0_{2}$, Tag-Heuer, and Virgin were analyzed.

\section{Confirmatory Factor Analysis}

To validate the scales used and test for convergent and discriminant validity, all independent and dependent latent variables were included in one multifactorial confirmatory model (CFA) with a robust maximum likelihood estimation method (MLR).

To check for systematic response patterns, common method bias was calculated with the use of the common latent factor method (Podsakoff, MacKenzie, Lee, \& Podsakoff, 2003). The indicators of all constructs were specified to freely load into a single factor (unconstrained same-source model). The unconstrained model was later compared to a constrained model (the same-source factor loadings were constrained to zero). The fit of the unconstrained model was worse than the constrained model, suggesting that common method bias does not pose a problem in the analysis (Podsakoff et al., 2003).

To estimate the multifactorial CFA model, each item was specified to load into its specific factor and the error terms were independent, hence the 
measurements were unidimensional. All the standardized loadings estimates were statistically significant and greater than 0.60 . The $t$ values ranged from 13.91 to $51.50(p<0.001)$. No evidence of cross-loading among the items was identified. The above-mentioned tests support convergent validity of the constructs used (Kline, 2011).

The average variance extracted (AVE) was computed for each latent variable. The AVE scores ranged from 0.63 to 0.78 and were above the acceptable threshold of 0.50 (Bagozzi \& Yi, 1988). The square roots of the AVE scores were higher than the correlations across the factors. Those tests evidence discriminant validity (Kline, 2011).

The following indexes served to assess the CFA model's goodness-of-fit (GOF): the chi-square test statistic, the comparative fit index (CFI), the Tucker-Lewis index (TLI), and the root mean square error of approximation (RMSEA). Values above the threshold of 0.90 for CFI and TLI and below 0.08 for RMSEA indicate a good fit of the model to the data (Kline, 2011). The results of the CFA indicate that the five-factor model had an excellent fit with the data. The GOF values were as follows: $\operatorname{MLR} \chi^{2}(109)=180.24, \operatorname{CFI}=0.97$, $\mathrm{TLI}=0.96$, and RMSEA $=0.04[90 \%$ confidence interval (CI): 0.03-0.05]. The scaling correction factor (SCF) for the MLR estimation was 1.37.

Finally, the composite reliability (CR) and factor determinacy (FD) coefficient helped establish reliability. The $\mathrm{CR}$ values ranged from 0.85 to 0.91 and exceed the recommended 0.70 threshold value (Bagozzi \& Yi, 1988). The FD coefficients for the five-factor CFA model ranged from
0.94 to 0.96 and were above the desired threshold of 0.80 (Muthén \& Muthén, 2012). The CR and FD coefficients support the internal consistency of the subscales. Table 1 presents the reliability and validity outcomes resulting from the CFA analysis.

\section{Structural Equation Model}

To test the directional hypotheses, all five latent variables were included in a single structural model. The MLR estimator was used. The results of the SEM indicate that the five-factor structural model had a good fit to the data. The GOF values were as follows: $\operatorname{MLR} \chi^{2}(111)=181.38, \mathrm{CFI}=0.97$, $\mathrm{TLI}=0.96$, and RMSEA $=0.04$ (90\% CI: $0.03-$ 0.05). The SCF for MLR was 1.36.

Presented in Table 2 is a summary of the computations relating to the tests of the hypotheses in this study. Firm-created and user-generated SM brandrelated communication positively influenced brand attitude, which confirmed hypotheses H1a $(\beta=$ $0.32 ; t$ value $=3.73 ; p$ value $=0.001)$ and $\mathrm{H} 1 \mathrm{~b}(\beta=$ $0.30 ; t$ value $=4.04 ; p$ value $=0.001)$. Firmcreated SM brand-related communication showed no influence on event attitude, leading to the rejection of $\mathrm{H} 2 \mathrm{a}$ ( $p$ value $=0.12$ ). On the other hand, user-generated SM brand-related communication positively influenced event attitude, which confirmed hypothesis $\mathrm{H} 2 \mathrm{~b}(\beta=0.24 ; t$ value $=2.62$; $p$ value $=0.01)$.

Brand attitude has shown to positively influence event attitude, thus supporting $\mathrm{H} 3$ ( $\beta=0.33$; $t$ value $=4.59 ; p$ value $=0.001)$.

Table 1

Reliability and Validity Scores of the Conceptual Model

\begin{tabular}{lcccccccc}
\hline Construct & CR & FD & AVE & 1 & 2 & 3 & 4 & 5 \\
\hline $\begin{array}{l}\text { 1. Firm-created social media } \\
\quad \text { communication }\end{array}$ & 0.89 & 0.95 & 0.67 & 0.81 & & & \\
2. User-generated social media & 0.87 & 0.94 & 0.63 & 0.55 & 0.79 & & & \\
$\quad$ communication & 0.90 & 0.95 & 0.75 & 0.49 & 0.48 & 0.86 & & \\
3. Brand attitude & 0.91 & 0.96 & 0.78 & 0.42 & 0.47 & 0.51 & 0.88 & \\
4. Event attitude & 0.85 & 0.95 & 0.66 & 0.12 & 0.20 & 0.21 & 0.36 & 0.81 \\
5. Intention to participate &
\end{tabular}

Note. The square root of the average variance extracted values appear in italics. CR, composite reliability; FD, factor determinacy; AVE, average variance extracted. $\operatorname{MLR} \chi^{2}(109)=180.24, \mathrm{CFI}=0.97$, TLI $=$ 0.96 , and RMSEA $=0.04$ (90\% CI: 0.03-0.05); $n=307$. 
Table 2

Standardized Structural Coefficients of the Conceptual Model

\begin{tabular}{|c|c|c|c|c|c|}
\hline Hypothesis & & $\beta$ & $t$ Value & $p$ Value & $\begin{array}{l}\text { Acceptance/ } \\
\text { Rejection }\end{array}$ \\
\hline \multicolumn{2}{|l|}{ H1a. FCC $\rightarrow$ Brand attitude } & 0.32 & 3.73 & 0.001 & Accepted \\
\hline \multicolumn{2}{|l|}{ H1b. UGC $\rightarrow$ Brand attitude } & 0.30 & 4.04 & 0.001 & Accepted \\
\hline \multicolumn{2}{|l|}{$\mathrm{H} 2 \mathrm{a} . \mathrm{FCC} \rightarrow$ Event attitude } & 0.12 & 1.52 & 0.12 & Rejected \\
\hline \multicolumn{2}{|l|}{$\mathrm{H} 2 \mathrm{~b} . \mathrm{UGC} \rightarrow$ Event attitude } & 0.24 & 2.62 & 0.01 & Accepted \\
\hline \multicolumn{2}{|l|}{ H3. Brand attitude $\rightarrow$ Event attitude } & 0.33 & 4.59 & 0.001 & Accepted \\
\hline \multicolumn{2}{|l|}{ H4. Brand attitude $\rightarrow$ Intention to participate } & 0.03 & 0.48 & 0.62 & Rejected \\
\hline \multicolumn{2}{|l|}{ H5. Event attitude $\rightarrow$ Intention to participate } & 0.34 & 4.29 & 0.001 & Accepted \\
\hline Mediation Analysis & $\begin{array}{l}\text { Specific } \\
\text { Indirect } \beta\end{array}$ & $\begin{array}{l}\text { 95\% Confidence } \\
\text { Interval }\end{array}$ & $t$ Value & $p$ Value & $\begin{array}{l}\text { Acceptance/ } \\
\text { Rejection }\end{array}$ \\
\hline \multicolumn{6}{|l|}{ Indirect effects } \\
\hline \multicolumn{6}{|l|}{$\begin{array}{l}\text { H6a. FCC } \rightarrow \text { Brand attitude } \rightarrow \text { Intention to } \\
\text { participate }\end{array}$} \\
\hline $\begin{array}{l}\text { H6b. FCC } \rightarrow \text { Event attitude } \rightarrow \text { Intention to } \\
\text { participate }\end{array}$ & 0.03 & $-0.01-0.08$ & 1.28 & 0.19 & Rejected \\
\hline $\begin{array}{l}\mathrm{H} 7 \mathrm{a} . \mathrm{UGC} \rightarrow \text { Brand attitude } \rightarrow \text { Intention to } \\
\text { participate }\end{array}$ & 0.01 & $-0.03-0.05$ & 0.41 & 0.67 & Rejected \\
\hline $\begin{array}{l}\mathrm{H} 7 \mathrm{~b} \text {. UGC } \rightarrow \text { Event attitude } \rightarrow \text { Intention to } \\
\text { participate }\end{array}$ & 0.08 & $0.02-0.13$ & 2.25 & 0.02 & Accepted \\
\hline $\begin{array}{l}\text { H8a. FCC } \rightarrow \text { Brand attitude } \rightarrow \text { Event } \\
\text { attitude }\end{array}$ & 0.12 & $0.04-0.19$ & 2.77 & 0.001 & Accepted \\
\hline $\begin{array}{l}\text { H8b. UGC } \rightarrow \text { Brand attitude } \rightarrow \text { Event } \\
\text { attitude }\end{array}$ & 0.11 & $0.02-0.20$ & 2.21 & 0.02 & Accepted \\
\hline $\begin{array}{l}\text { H9a. FCC } \rightarrow \text { Brand attitude } \rightarrow \text { Event } \\
\text { attitude } \rightarrow \text { Intention to participate }\end{array}$ & 0.03 & $0.01-0.06$ & 2.24 & 0.02 & Accepted \\
\hline $\begin{array}{l}\mathrm{H} 9 \mathrm{~b} . \mathrm{UGC} \rightarrow \text { Brand attitude } \rightarrow \text { Event } \\
\text { attitude } \rightarrow \text { Intention to participate }\end{array}$ & 0.03 & $0.01-0.05$ & 1.81 & 0.06 & Accepted \\
\hline $\begin{array}{l}\text { H10. Brand attitude } \rightarrow \text { Event attitude } \rightarrow \\
\text { Intention to participate }\end{array}$ & 0.12 & $0.04-0.20$ & 2.68 & 0.001 & Accepted \\
\hline Total effects & & & & & \\
\hline $\mathrm{FCC} \rightarrow$ Intention to participate & 0.09 & $0.03-0.15$ & 2.58 & 0.01 & \\
\hline $\mathrm{UGC} \rightarrow$ Intention to participate & 0.13 & $0.07-0.18$ & 3.79 & 0.001 & \\
\hline
\end{tabular}

Note. FCC, firm-created SM brand-related communication; UGC, user-generated SM brand-related communication; SEM model: $\operatorname{MLR} \chi^{2}(111)=181.38, \mathrm{CFI}=0.97, \mathrm{TLI}=0.96$, and RMSEA $=0.04(90 \%$ CI: $0.03-0.05) ; n=307$. Mediational model: $\operatorname{ML} \chi^{2}(111)=248.30, \mathrm{CFI}=0.96$, TLI $=0.95$, and RMSEA $=0.06(90 \% \mathrm{CI}: 0.05-0.07)$; number of bootstrap draws $=5,000$.

Finally, the calculations revealed that brand attitude has no influence on the consumer's intention to participate in a brand event, leading to the rejection of $\mathrm{H} 4$ ( $p$ value $=0.62$ ). Event attitude was shown to have a positive influence on the consumer's intention to participate in a brand event, providing support for $\mathrm{H} 5$ ( $\beta=0.34 ; t$ value $=4.29$; $p$ value $=0.001)$. The standardized estimates for the final model are illustrated in Figure 2.

\section{Mediation Analysis}

To test the mediational role of brand and event attitudes on the relationship between SM brand-related communication and the consumer's intention to participate in a brand-sponsored event, the five-factor model specification was used. The estimator used for the computations was the maximum likelihood (ML) (Muthén \& Muthén, 2012). The mediation analysis was performed with 5,000 bootstrap draws.

The GOF values for the mediational model follow: $\operatorname{ML} \chi^{2}(111)=248.30, \mathrm{CFI}=0.96$, TLI $=0.95$, and $\mathrm{RMSEA}=0.06(90 \% \mathrm{CI}: 0.05-0.07)$. The results indicate a good fit to the data.

Presented in Table 2 is a summary of the mediation analysis. The first set of hypotheses verified the mediational role of brand attitude and event attitude on the relationship between firm-created 


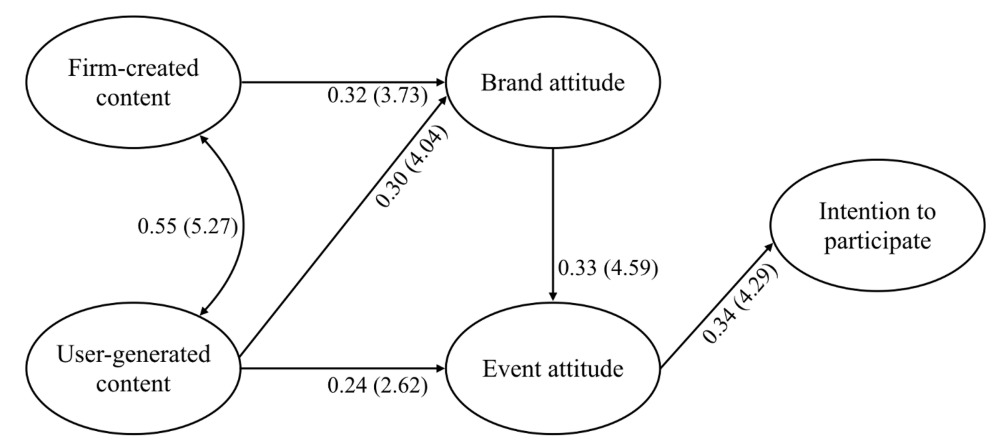

Figure 2. Standardized direct estimates for the conceptual model. The $t$ values are denoted in parentheses. $\operatorname{MLR} \chi^{2}(111)=181.38, \mathrm{CFI}=0.97, \mathrm{TLI}=0.96$, and RMSEA $=0.04$ (90\% CI: $0.03-0.05) ; n=307$.

SM brand-related communication and the consumer's intention to participate in a brand event. The results did not support the hypotheses, leading to the rejection of H6a $(p$ value $=0.66)$ and $\mathrm{H} 6 \mathrm{~b}$ $(p$ value $=0.19)$.

The second set of hypotheses tested for the mediational role of consumers' attitudes on the relationship between user-generated SM brand-related communication and the intention to participate in a brand event. Brand attitude did not mediate the relationship ( $p$ value $=0.67$ ), thus rejecting $\mathrm{H7a}$. On the other hand, the consumer's event attitude demonstrated to indirectly influence the relationship between UGC and intention to participate in a brand event, supporting $\mathrm{H} 7 \mathrm{~b}$ (ind. $\beta=0.08$; $t$ value $=$ $2.25 ; p$ value $=0.02$ ).

Following, the indirect effects were calculated to test the mediational effect of brand attitude on the relationship between SM brand-related communication and the consumer's brand event attitude. The results were statistically significant for both firm-created (ind. $\beta=0.12 ; t$ value $=2.77$; $p$ value $=0.001$ ) and user-generated (ind. $\beta=0.11$; $t$ value $=2.21 ; p$ value $=0.02$ ) types of SM brandrelated communication, leading to the support of $\mathrm{H} 8 \mathrm{a}$ and $\mathrm{H} 8 \mathrm{~b}$.

The fourth set of hypotheses verified the chain of effects originating from both types of SM brandrelated communication through consumers' attitudes (brand and event), leading to intention to participate. The indirect effects were statistically significant and supported both $\mathrm{H} 9 \mathrm{a}$ (ind. $\beta=0.03$; $t$ value $=2.24 ; p$ value $=0.02$ ) and $\mathrm{H} 9 \mathrm{~b}$ (ind. $\beta=$ $0.03 ; t$ value $=1.81 ; p$ value $=0.06$ ).
Finally, the indirect effect from brand attitude on consumers' intention to participate through the mediation of event attitude was computed. The results also supported $\mathrm{H} 10$ (ind. $\beta=0.12 ; t$ value = 2.68; $p$ value $=0.001$ ) leading to its acceptance. The total effects computed were as follows: firmcreated SM brand-related communication on the intention to participate in brand events (total $\beta=$ $0.09 ; t$ value $=2.58 ; p$ value $=0.01)$; user-generated SM brand-related communication on the intention to participate in brand events (total $\beta=0.13$; $t$ value $=3.79 ; p$ value $=0.001)$.

\section{Discussion}

SM communication was suggested to influence consumers on their decision process of participating in events (Hudson et al., 2015). Despite the relevance of evaluating this proposition, the effects of SM brand-related communications on event attendance were still not empirically validated. In order to address this literature gap, the current research pursued two research objectives. First, to evaluate whether firm-created and user-generated SM brandrelated content influenced consumers' attitudes and, consequently, their intentions to participate in brand-sponsored events. The second objective intended to examine the mediating role of consumers' attitudes towards the brand and the event on the relationship between SM brand-related communication and intention to participate in brand-sponsored events. The findings contribute to practitioners and scholars in the field of events marketing, with special interest for brand-sponsored events. 
Initially SM brand-related communications were evaluated for their direct effects on brand attitude and event attitude ( $\mathrm{H} 1$ and $\mathrm{H} 2$ ), while distinguishing the results among the type of content sources (firm created and user generated). The results validate the positive effects of SM brand-related communications on brand attitude for both types of content sources. Hence, when consumers hold positive evaluations of the content they are exposed to, finding it gratifying, an enhancement of brand evaluations occur (Jahn \& Kunz, 2012; Shao, 2009; Zhang et al., 2010).

However, when the direct effects of SM brandrelated communications on event attitude are considered, the results differ between content sources. Whereas user-generated SM brand-related content has its effects on event attitude being supported, the influence of firm-created SM brand-related content is not significant. These effects were originally hypothesized as a consequence of the enthusiasm and positivity that occurs when consumers hold positive evaluations of the content they are exposed to with impact towards other initiatives promoted by the brand (Bagozzi \& Dholakia, 2006). The results indicate that the arguments offered in support for the hypotheses do not account for the existing differences between the two types of SM brand-related content sources.

To elaborate on these differences, the current authors propose the use of the theory of identification, which helps to explain how media characters' influence consumers' behaviors in mediated contexts (Cohen, 2001). Identification with media characters results from consumers' imaginative processes occurring in response to characters presented in mediated contexts (e.g., SM context) (Cohen, 2001). Along this process, consumers merge their own self-identity with the identity of the media character, internalizing their behaviors and thoughts and enjoying feelings of affinity, friendship, liking, and similarity (Cohen, 2001). In the specific context of firm-created SM brandrelated content the main media character is the brand (not human), while in user-generated context the media characters are humans, represented by consumers' friends and other SM influencers, such as bloggers. In view of that, we may assume that consumers develop a stronger sense of identification with media characters presented in user-generated contexts influencing, as a consequence, the effects on event attitude. Hence, the rationale is that consumers hold more positive evaluations towards events that are sponsored by brands that are talked about by others with whom they most identify with.

In the following hypothesis ( $\mathrm{H} 3)$ brand attitude was confirmed for its direct effects on event attitude. This result contributes to the literature on events marketing by evidencing the mechanism of image transfer (Keller \& Lehmann, 2003; Ruth et al., 2003) occurring between the brand and the brand-sponsored event, with brand attitudes influencing consumers' evaluations regarding the attractiveness of events that are sponsored by the brand.

Further, $\mathrm{H} 4$ and $\mathrm{H} 5$ investigated the direct effect of brand attitude and event attitude on consumers' behavioral intentions to participate in a brand-sponsored event. The hypothesized effects were built on the evidence that consumers elaborate behavioral intentions regarding the objects towards which they hold positive evaluations (Brown \& Stayman, 1992; Michelini et al., 2017). This argument helped to validate the effects of event attitude on consumers' behavioral intentions to participate in brand-sponsored events. However, it did not offer support for the effects of brand attitudes. The findings reveal that liking a brand and appreciating it in general terms does not imply on its own that consumers will wish to participate in an event that is sponsored by the brand. The current authors interpret this outcome in view of events' experiential nature (Altschwager et al., 2015; Close, Krishen, \& Latour, 2009; Zarantonello \& Schmitt, 2013). During events, consumers are immersed and encouraged to actively participate and enjoy various emotional and cognitive benefits (e.g., relaxation, socialization, cultural entertainment) (Hixson et al., 2011). In the context of brand-sponsored events, brands simultaneously perform the role of enablers of these benefits and participating actors in the experience (Close et al., 2009; Zarantonello \& Schmitt, 2013). Hence, while elaborating their behavioral intentions towards participation in brand-sponsored events, consumers take into consideration their evaluations towards brands specific capabilities as enablers and participating actors in creating 
experiences. As these aspects differ from general brand liking, they might explain the results obtained in $\mathrm{H} 4$.

The mediational hypotheses also offer important insights. In general, most of the mediating effects were supported. While analyzing specific paths, three important findings might be depicted. First, the important role of brand attitude as it mediates the positive effects between SM brandrelated communications and event attitude. This mediating path (SM communications $\rightarrow$ brand attitude $\rightarrow$ event attitude) is crucial for both types of content sources, with particular relevance for the content created by firms, as this type of SM brand-related content showed no significant effect on event attitude (as already discussed). Second, event attitude was proved as the main backbone in the conceptual model, mediating the relations between SM brand-related communications, brand attitude, and behavioral intentions. Third, provided that the total effects are considered, usergenerated content accounts for higher effects compared to firm-created content. This difference is due the significant direct and mediated paths of user-generated SM brand-related content on event attitude.

In view of the findings discussed, the present study offers various contributions to literature and managerial practice. The first contribution to the body of literature in SM and events marketing refers to validating the effects of SM brand-related communications on generating consumers' intentions to participate in brand-sponsored events. This result extends previous findings that were focused on validating the effects of SM communications on transactional brand-related behaviors (Bruhn et al., 2012; Schivinski \& Dabrowski, $2015,2016)$ with no attention given to nontransactional brand-related behaviors like consumers' intentions to participate in brand-sponsored events.

The current study also succeeds in validating the mediating role of consumers' attitudes, which were not previously investigated in the SM context. The analysis of specific mediating effects revealed that brand attitude and event attitude played roles that were substantially different. Whereas brand attitude was proven to mediate the effects of SM brand-related communications on event attitude, the last one was mostly validated as the backbone of the conceptual framework, driving all the significant effects on consumers' behavioral intentions. In view of these results and the experiential nature of events (Altschwager et al., 2015; Close et al., 2009; Zarantonello \& Schmitt, 2013), the findings indicate that brand attitudes only have a positive effect on behavioral intentions when they are able to positively impact consumers' evaluations of the experience expected while participating in a brand-sponsored event. To leverage consumers' behavioral responses, it is recommended that brands promote their brandsponsored events with encouraging language on SM that involves the user and educates the consumer on the brand-sponsored event in order to fortify their positive event evaluations sourced from their brand attitude. Further, managers are advised to focus on encouraging user-generated brand content to increase consumers' brand attitude by influencing users to share and repost content from their pages. Moreover, to actively involve social influencers (i.e., bloggers) in their marketing strategy to further utilize usergenerated content.

Additionally, as the findings help to validate the role of consumers' attitudes as antecedents to event attendance, they extend the literature in events marketing beyond antecedents related to individual motivations (Hall et al., 2010; Wohlfeil \& Whelan, 2006) and identification with the event promoter (Mohan \& Thomas, 2012), while considering the influences of SM brand-related communication. Therefore, extending the rationale with the suggestion to activate and encourage further interaction of consumers through social influencers and user-generated content that exuberates positive consumer attitudes towards the brand.

Finally, as the study concludes for stronger effects imprinted by user-generated brand-related content, it reinforces previous directions (Schivinski \& Dabrowski, 2015, 2016) and extends the events marketing literature with evidences on the superior impact of users as influencers on generating positive behavioral intentions regarding brand-sponsored events.

Among the implications for practice, the authors denote the acceptance of SM communications as 
a positive driver of attendance to brand-sponsored events. The relevance of this result needs to be interpreted in view of the increasing adoption of events in brands' promotional budgets and consequently the relevance of brands capabilities to attract consumers' participation. While evaluating the antecedents of consumers' intentions to participate in brand-sponsored events, the current study distinguishes the effects among the types of SM content sources. The differences of SM brandrelated communication sources challenge brands to increasingly create satisfying content and simultaneously recruit and motivate individuals to generate their own brand-related content. This scenario positions effective SM brand-related communications as resulting from a complex arrangement of efforts with firms being requested to develop capabilities as content creators able to influence brand-related interactions both directly (e.g., firmcreated content) and indirectly (e.g., user-generated content).

Regarding user-generated content, the current findings further suggest that recruiting influencers, which consumers identify with might be an important aspect, as individuals tend to internalize their behaviors and thoughts, with potential impact on their evaluations of brand-sponsored events.

Furthermore, the findings invite managers to distinguish the effects of SM brand-related communications on brand evaluations in general from the effects on event attitudes in specific. The results suggest that in order to influence consumers' behavioral intentions to participate in an event sponsored by the brand, practitioners need to develop their SM brand-related communications in the sense of reinforcing consumers' perceptions on their capabilities as enablers and participating actors in events' immersed experiences. This implies that brands are perceived as entities capable of driving experiences that deliver on aspects like relaxation, enjoyment, and socialization, and therefore generate positive evaluation towards events that are sponsored by the brand. To optimize consumers' event perceptions, it is advised to managers to advertise their brand-sponsored events with consistent and continuous SM messaging before, during, and after the event, portraying the experiences and molding the consumers' current and future expectations.

Although the current study offers a significant contribution to theory and practice, findings need to be interpreted in view of some intrinsic limitations, which may provide guidelines for future studies. As the present research does not discriminate results among the type of SM platforms or brands, future studies may evaluate this aspect as SM brand-related communications may differ across platforms (Smith et al., 2012) and types of brands (e.g., hedonic vs. functional; brand selfexpressiveness) (Dodd, Pinkelton, \& Gustafson, 1996; Wallace et al., 2014). Moreover, the criteria used to operationalize event attitude has captured general evaluations and intentions endowed by the brand and did not account for specific event types (e.g., music, sports) or individual preferences. Future studies could explore the role of event types on influencing the strength of effects in view of individual preferences and brand-event fit (X. T. B. Low \& Pyun, 2016; Wohlfeil \& Whelan, 2006). Regarding the effects of consumers' attitudes on behavioral intentions, future studies might consider additional constructs for analysis as suggested in previous studies which explored the Theory of Reasoned Action in the context of tourism and events (Han et al., 2010; Prayag et al., 2013; Quintal et al., 2010).

Finally, future studies could also explore the arguments proposed for justifying the hypotheses that were not supported. More specifically, research could evaluate the influence of the consumers' identifications with media characters in their event attitudes. Also, further investigation could explore the specific aspects that may drive consumers' perceptions regarding brand capabilities as enablers and participating agents in brandsponsored events.

\section{Acknowledgement}

Christina Shaw is a graduate from Nottingham Business School, Nottingham Trent University, with a first-class honors B.A. degree in Business Management and Marketing. This research article was part of her final year project at the Business School during her undergraduate degree. 
Appendix: Descriptive Statistics for the Constructs and Measurements

\begin{tabular}{|c|c|c|c|c|c|c|c|}
\hline Constructs and Measurements & $\begin{array}{l}\text { Standardized } \\
\text { Factor Loading }\end{array}$ & $t$-Value & Mean & $S D$ & Skewness & Kurtosis & $R^{2}$ \\
\hline \multicolumn{8}{|c|}{ Firm-created social media content (Schivinski \& Dabrowski, 2015) } \\
\hline $\begin{array}{l}\text { I am satisfied with the company's social media } \\
\text { communications for [Brand X] }\end{array}$ & 0.84 & 28.15 & 5.43 & 1.40 & -1.18 & 1.17 & 0.70 \\
\hline $\begin{array}{l}\text { The level of the company's social media } \\
\text { communication for [Brand X] meets my } \\
\text { expectations }\end{array}$ & 0.87 & 34.86 & 5.47 & 1.41 & -1.22 & 1.21 & 0.76 \\
\hline $\begin{array}{l}\text { The company's social media communications } \\
\text { for }[\text { Brand } X] \text { are very attractive }\end{array}$ & 0.79 & 27.37 & 5.55 & 1.47 & -1.10 & 0.81 & 0.62 \\
\hline $\begin{array}{l}\text { The company's social media communications } \\
\text { for [Brand X] perform well, when compared } \\
\text { with the social media communications of } \\
\text { other brands }\end{array}$ & 0.79 & 25.22 & 5.22 & 1.49 & -0.92 & 0.53 & 0.63 \\
\hline \multicolumn{8}{|c|}{ User-generated social media content (Schivinski \& Dabrowski, 2015) } \\
\hline $\begin{array}{l}\text { I am satisfied with the content generated } \\
\text { on social media sites by other users about } \\
\text { [Brand X] }\end{array}$ & 0.88 & 46.44 & 5.16 & 1.31 & -0.64 & 0.30 & 0.78 \\
\hline $\begin{array}{l}\text { The level of the content generated on social } \\
\text { media sites by other users about [Brand X] } \\
\text { meets my expectations }\end{array}$ & 0.79 & 22.63 & 5.18 & 1.27 & -0.69 & 0.59 & 0.63 \\
\hline $\begin{array}{l}\text { The content generated by other users about } \\
{[\text { Brand } X] \text { is very attractive }}\end{array}$ & 0.79 & 32.56 & 5.05 & 1.33 & -0.46 & -0.03 & 0.63 \\
\hline $\begin{array}{l}\text { The content generated on social media sites by } \\
\text { others users about [Brand } \mathrm{X}] \text { performs well, } \\
\text { when compared with other brands }\end{array}$ & 0.73 & 15.10 & 5.19 & 1.33 & -0.63 & 0.16 & 0.53 \\
\hline \multicolumn{8}{|c|}{ Brand attitude (G. Low \& Lamb Jr., 2000; Villarejo-Ramos \& Sánchez-Franco, 2005) } \\
\hline I have a pleasant idea of [Brand X] & 0.85 & 31.03 & 6.09 & 1.15 & -1.58 & 2.69 & 0.73 \\
\hline$[$ Brand $\mathrm{X}]$ has a good reputation & 0.86 & 31.07 & 6.12 & 1.34 & -1.92 & 3.56 & 0.74 \\
\hline $\begin{array}{l}\text { I associate positive characteristics with } \\
\text { [Brand X] }\end{array}$ & 0.90 & 40.24 & 5.99 & 1.35 & -1.68 & 2.68 & 0.82 \\
\hline \multicolumn{8}{|c|}{ Event attitude (G. Low \& Lamb Jr., 2000; Villarejo-Ramos \& Sánchez-Franco, 2005) } \\
\hline $\begin{array}{l}\text { I have a pleasant idea of an event that is spon- } \\
\text { sored by [Brand X] }\end{array}$ & 0.82 & 28.58 & 5.14 & 1.59 & -0.612 & -0.19 & 0.68 \\
\hline $\begin{array}{l}\text { An event sponsored by [Brand X] has a good } \\
\text { reputation }\end{array}$ & 0.93 & 51.50 & 5.33 & 1.49 & -0.682 & -0.07 & 0.86 \\
\hline $\begin{array}{l}\text { I associate positive characteristics towards an } \\
\text { event that is sponsored by [Brand X] }\end{array}$ & 0.90 & 41.85 & 5.50 & 1.50 & -0.91 & 0.43 & 0.81 \\
\hline \multicolumn{8}{|l|}{ Intention to participate (Lee et al., 2012) } \\
\hline $\begin{array}{l}\text { I will frequently attend events sponsored by } \\
\text { [Brand X] I learn about on social media in } \\
\text { the future }\end{array}$ & 0.60 & 13.91 & 4.06 & 1.74 & -0.31 & -0.83 & 0.36 \\
\hline $\begin{array}{l}\text { I am most likely to go to an event sponsored } \\
\text { by }[\text { Brand X] after seeing events listed on } \\
\text { social media }\end{array}$ & 0.89 & 36.00 & 4.25 & 1.65 & -0.40 & -0.54 & 0.79 \\
\hline $\begin{array}{l}\text { The social media event listing will solidify my } \\
\text { decision to attend an event with }[\text { Brand } \mathrm{X}]\end{array}$ & 0.91 & 31.66 & 4.24 & 1.69 & -0.41 & -0.51 & 0.83 \\
\hline
\end{tabular}

References

Ajzen, I., \& Fishbein, M. (1980). Understanding attitudes and predicting social behaviour. Englewood Cliffs, NJ: Prentice Hall.

Altschwager, T., Goodman, S., Conduit, J., \& Habel, C. (2015). Branded marketing events: A proposed "experiential needs-based" conceptual framework. Event Management,
19(3), 381-390. doi: http://doi.org/10.3727/152599515X 14386220874887

Bagozzi, R. P., \& Dholakia, U. M. (2006). Antecedents and purchase consequences of customer participation in small group brand communities. International Journal of Research in Marketing, 23(1), 45-61. doi: http://doi.org/10.1016/j.ijresmar.2006.01. 005 
Bagozzi, R. P., \& Yi, Y. (1988). On the evaluation of structural equation models. Journal of the Academy of Marketing Science, 16(1), 74-94. doi: http://doi.org/10.1007/ BF02723327

Bambauer-Sachse, S., \& Mangold, S. (2011). Brand equity dilution through negative online word-of-mouth communication. Journal of Retailing and Consumer Services, 18(1), 38-45. doi: http://doi.org/10.1016/j. jretconser.2010.09.003

Berthon, P. R., Pitt, L. F., Plangger, K., \& Shapiro, D. (2012). Marketing meets Web 2.0, social media, and creative consumers: Implications for international marketing strategy. Business Horizons, 55(3), 261-271. doi: https:// doi.org/10.1016/j.bushor.2012.01.007

Blackwell, R. D., Miniard, P. W., \& Engel, J. F. (2001). Consumer behavior (9th ed.). Mason, $\mathrm{OH}$ : South-Western Thomas Learning.

Bloom, P. N., Hoeffler, S., Keller, K. L., \& Meza, C. E. B. (2006). How social-cause marketing affects consumer perceptions. MIT Sloan Management Review, 47(2), 47-56. doi: http://doi.org/10.1177/001088048802800410

Bogaert, M., Ballings, M., \& Van Den Poel, D. (2016). The added value of Facebook friends data in event attendance prediction. Decision Support Systems, 82, 196-203. doi: http://doi.org/10.1016/j.dss.2015.11.003

Brodie, R. J., Ilic, A., Juric, B., \& Hollebeek, L. (2013). Consumer engagement in a virtual brand community: An exploratory analysis. Journal of Business Research, 66(8), 105-114. doi: https://doi.org/10.1016/j.jbusres. 2011.07.029

Brown, S. P., \& Stayman, D. M. (1992). Antecedents and consequences of attitude toward the ad: A meta-analysis. Journal of Consumer Research, 19(1), 34-51. doi: http:// doi.org/10.1086/209284

Bruhn, M., Schnebelen, S., \& Schäfer, D. (2013). Antecedents and consequences of the quality of e-customerto-customer interactions in B2B brand communities. Industrial Marketing Management, 43(1), 164-176. doi: http://doi.org/10.1016/j.indmarman.2013.08.008

Bruhn, M., Schoenmueller, V., \& Schäfer, D. B. (2012). Are social media replacing traditional media in terms of brand equity creation? Management Research Review, 35(9), 770-790. doi: http://doi.org/10.1108/014091712 11255948

Chevalier, J. A., \& Mayzlin, D. (2006). The effect of word of mouth on sales: Online book reviews. Journal of Marketing Research, XLIII, 345-354. doi: https://doi. org/10.1509/jmkr.43.3.345

Christodoulides, G., Jevons, C., \& Bonhomme, J. (2012). Memo to marketers: Quantitative evidence for change. How user-generated content really affects brands. Journal of Advertising Research, 52(1), 53-64. doi: http:// doi.org/10.2501/JAR-52-1-053-064

Close, A., Krishen, A. S., \& Latour, M. (2009). This event is me! How consumer event-self-congruity leverages sponsorship. Journal of Advertising Research, 49(3), 271-284. doi: http://doi.org/10.2501/S002184990909 0412
Cohen, J. (2001). Defining identification: A theoretical look at the identification of audiences with media characters. Mass Communication \& Society, 4(3), 245-264. doi: https://doi.org/10.1207/S15327825MCS0403_01

Conner, M., \& Armitage, C. J. (1998). Extending the theory of planned behavior: A review and avenues for further research. Journal of Applied Social Psychology, 28, 1429-1464. doi: http://doi.org/10.1111/j.15591816.1998.tb01685.x

Cui, G., Lui, H.-K., Chan, T.-S., \& Joy, A. (2012). Decomposition of cross-country differences in consumer attitudes toward marketing. Journal of Consumer Marketing, 29(3), 214-224. doi: http://doi.org/10.1108/ 07363761211221747

de Vries, L., Peluso, A. M., Romani, S., Leeflang, P. S. H., \& Marcati, A. (2017). Explaining consumer brand-related activities on social media: An investigation of the different roles of self-expression and socializing motivations. Computers in Human Behavior, 75, 272-282. doi: http:// doi.org/10.1016/j.chb.2017.05.016

Dodd, T. H., Pinkelton, B. E., \& Gustafson, A. W. (1996). External information sources of product enthusiasts: Differences between variety seekers, variety neutrals, and variety avoiders. Psychology \& Marketing, 13(3), 291-304. doi: https://doi.org/10.1002/(SICI)1520-6793 (199605)13:3<291::AID-MAR3>3.0.CO;2-7

Fazio, R. H., Powell, M. C., \& Williams, C. J. (1989). The role of attitude accessibility in the attitude-to-behavior process. Journal of Consumer Research, 16(3), 280-288. doi: http://doi.org/10.1086/209214

Field, A. (2013). Andy Field-Discovering statistics using SPSS: And sex and drugs and rock " $n$ " roll. Thousand Oaks, CA: SAGE Publications.

Filo, K., Funk, D. C., \& Hornby, G. (2009). The role of web site content on motive and attitude change for sport events. Journal of Sport Management, 23(1), 21-40. doi: http://doi.org/10.1123/jsm.23.1.21

Filo, K., Lock, D., \& Karg, A. (2015). Sport and social media research: A review. Sport Management Review, 18(2), 166-181. doi: http://doi.org/10.1016/j.smr.2014.11.001

Fishbein, M., \& Ajzen, I. (1975). Belief, attitude, intention and behavior: An introduction to theory and research. Reading, MA: Addison-Wesley.

Gwinner, K. (1997). A model of image creation and image transfer in event sponsorship. International Marketing Review, 14(3), 145-158. doi: http://doi. org/10.1108/02651339710170221

Gyimóthy, S., \& Larson, M. (2015). Social media cocreation strategies: The 3Cs. Event Management, 19(3), 331-348. doi: http://doi.org/10.3727/152599515X14386 220874760

Hall, J., O’Mahony, B., \& Vieceli, J. (2010). An empirical model of attendance factors at major sporting events. International Journal of Hospitality Management, 29(2), 328-334. doi: http://doi.org/10.1016/j.ijhm.2009.10.011

Han, H., Hsu, L. T. (Jane), \& Sheu, C. (2010). Application of the theory of planned behavior to green hotel choice: Testing the effect of environmental friendly activities. 
Tourism Management, 31(3), 325-334. doi: http://doi. org/10.1016/j.tourman.2009.03.013

Hixson, E. J., Mccabe, S. V. S., \& Brown, G. (2011). Event attendance motivation and place attachment: An exploratory study of young residents in Adelaide, South Australia. Event Management, 15(3), 233-243. doi: http:// doi.org/10.3727/152599511X13124625650539

Hoeffler, S., \& Keller, K. L. (2002). Building brand equity through corporate societal marketing. Journal of Public Policy \& Marketing, 21(1), 78-89. doi: http://doi. org/10.1509/jppm.21.1.78.17600

Hoksbergen, E., \& Insch, A. (2016). Facebook as a platform for co-creating music festival experiences. International Journal of Event and Festival Management, 7(2), 84-99. doi: http://doi.org/10.1108/IJEFM-02-20160012

Hootsuite. (2017). Digital in 2017: Global overview. Retrieved from https://wearesocial.com/special-reports/ digital-in-2017-global-overview

Hudson, S., Roth, M. S., Madden, T. J., \& Hudson, R. (2015). The effects of social media on emotions, brand relationship quality, and word of mouth: An empirical study of music festival attendees. Tourism Management, 47, 68-76. doi: http://doi.org/10.1016/j.tourman. 2014.09.001

Huotari, L., Ulkuniemi, P., Saraniemi, S., \& Mäläskä, M. (2015). Analysis of content creation in social media by B2B companies. Journal of Business \& Industrial Marketing, 30(6), 761-770. doi: http://doi.org/10.1108/ JBIM-05-2013-0118

Hutter, K., Hautz, J., Dennhardt, S., \& Füller, J. (2013). The impact of user interactions in social media on brand awareness and purchase intention: The case of MINI on Facebook. Journal of Product \& Brand Management, 22(5), 342-351. doi: http://doi.org/10.1108/JPBM-052013-0299

Ibrahim, N. F., Wang, X., \& Bourne, H. (2017). Exploring the effect of user engagement in online brand communities: Evidence from Twitter. Computers in Human Behavior, 72, 321-338. doi: http://doi.org/10.1016/j. chb.2017.03.005

Jaakkola, E., \& Alexander, M. (2014). The role of customer engagement behavior in value co-creation. Journal of Service Research, 17(3), 247-261. doi: http://doi. org/10.1177/1094670514529187

Jahn, B., \& Kunz, W. (2012). How to transform consumers into fans of your brand. Journal of Service Management, 23(3), 344-361. doi: http://doi. org/10.1108/09564231211248444

Keller, K. L. (1993). Conceptualizing, measuring, and managing customer-based brand equity. Journal of Marketing, 57, 1-22. doi: http://doi.org/10.2307/1252054

Keller, K. L., \& Lehmann, D. (2003). How do brands create value? Marketing Management, 5, 27-31.

Kim, W. G., \& Kim, H.-B. (2004). Measuring customer-based restaurant brand equity: Investigating the relationship between brand equity and firm's performance. The Cornell Hotel and Restaurant
Administration Quarterly, 45(2), 115-131. doi: http:// doi.org/10.1177/0010880404264507

Kline, R. B. (2011). Principles and practice of structural equation modeling (3rd ed.). New York, NY: The Guilford Press.

Kumar, A., Bezawada, R., Rishika, R., Janakiraman, R., \& Kannan, P. K. (2016). From social to sale: The effects of firm-fenerated content in social media on customer behavior. Journal of Marketing, 80(1), 7-25. doi: http:// doi.org/10.1509/jm.14.0249

Langaro, D., Rita, P., \& de Fátima Salgueiro, M. (2015). Do social networking sites contribute for building brands? Evaluating the impact of users' participation on brand awareness and brand attitude. Journal of Marketing Communications, 7266, 1-23. doi: http://doi.org/10.1080/ 13527266.2015.1036100

Laroche, M., Habibi, M. R., Richard, M.-O., \& Sankaranarayanan, R. (2012). The effects of social media based brand communities on brand community markers, value creation practices, brand trust and brand loyalty. Computers in Human Behavior, 28(5), 1755-1767. doi: http://doi.org/10.1016/j.chb.2012.04.016

Lee, W., Xiong, L., \& Hu, C. (2012). The effect of Facebook users' arousal and valence on intention to go to the festival: Applying an extension of the technology acceptance model. International Journal of Hospitality Management, 31(3), 819-827. doi: http://doi.org/10.1016/ j.ijhm.2011.09.018

Leung, D., Law, R., van Hoof, H., \& Buhalis, D. (2013). Social media in tourism and hospitality: A literature review. Journal of Travel and Tourism Marketing, 30(1-2), 3-22. doi: http://doi.org/10.1080/10548408. 2013.750919

Low, G., \& Lamb Jr., C. (2000). The measurement and dimensionality of brand associations. Journal of Product \& Brand Management, 9(6), 350-370. doi: https://doi. org/10.1108/10610420010356966

Low, X. T. B., \& Pyun, D. Y. (2016). Consumers' perceived functions of and attitude toward corporate sponsors of small-scale amateur sporting events. Event Management, 20(2), 227-238. doi: http://doi.org/10.3727/152599516X 14643674421771

Michelini, L., Iasevoli, G., \& Theodoraki, E. (2017). Event venue satisfaction and its impact on sponsorship outcomes. Event Management, 21(3), 319-331. doi: http:// doi.org/10.3727/152599517X14942648527536

Mohan, L. J., \& Thomas, L. (2012). Effect of identification on attendance at team sporting events. Event Management, 16, 341-349. doi: http://doi.org/10.1057/thr.2010.1

Moro, S., Rita, P., \& Vala, B. (2016). Predicting social media performance metrics and evaluation of the impact on brand building: A data mining approach. Journal of Business Research, 69(9), 3341-3351. doi: http://doi. org/10.1016/j.jbusres.2016.02.010

Muntinga, D. G., Smit, E., \& Moorman, M. (2012). Social media DNA: How brand characteristics shape COBRAs. Advances in Advertising Research, III, 121-137. doi: http://doi.org/10.1007/978-3-8349-4291-3 
Muthén, L., \& Muthén, B. (2012). Statistical analysis with latent variables: Mplus user's guide (7th ed.). Los Angeles, CA: Authors.

Olson, J., \& Mitchell, A. (1981). Are product attribute beliefs the only mediator of advertising effects on brand attitude? Journal of Marketing Research, XVIII(8), 318-332.

Organisation for Economic Co-operation and Development. (2007). Participative web and user-created content: Web 2.0 wikis and social networking. Paris, France: Author.

Peter, J. P., \& Olson, J. (2009). Consumer behavior \& marketing strategy (9th ed.). Maidenhead, UK: McGrawHill/Irwin.

Podsakoff, P. M., MacKenzie, S. B., Lee, J.-Y., \& Podsakoff, N. P. (2003). Common method biases in behavioral research: A critical review of the literature and recommended remedies. Journal of Applied Psychology, 88(5), 879-903.

Pradhan, D., Duraipandian, I., \& Sethi, D. (2016). Celebrity endorsement: How celebrity-brand-user personality congruence affects brand attitude and purchase intention. Journal of Marketing Communications, 22(5), 456-473. doi: http://doi.org/10.1080/13527266.2014.914561

Prayag, G., Hosany, S., Nunkoo, R., \& Alders, T. (2013). London residents' support for the 2012 Olympic Games: The mediating effect of overall attitude. Tourism Management, 36, 629-640. doi: http://doi.org/10.1016/j. tourman.2012.08.003

Quintal, V. A., Lee, J. A., \& Soutar, G. N. (2010). Risk, uncertainty and the theory of planned behavior: A tourism example. Tourism Management, 31(6), 797-805. doi: http://doi.org/10.1016/j.tourman.2009.08.006

Ruth, J. A., Ruth, J. A., Simonin, B. L., \& Simonin, B. L. (2003). Brought to you by brand A and brand B. Journal of Advertising, 32(3), 19-30.

Ryan, M., \& Bonfield, E. H. (1975). The Fishbein extended model and consumer behavior. Journal of Consumer Research, 2(2), 118-136.

Schivinski, B., Christodoulides, G., \& Dabrowski, D. (2016). Measuring consumers' engagement with brand-related social-media content: Development and validation of a scale that identifies levels of social-media engagement with brands. Journal of Advertising Research, 56(1), 64-80. doi: http://doi.org/10.2501/JAR-2016-004

Schivinski, B., \& Dabrowski, D. (2015). The impact of brand communication on brand equity through Facebook. Journal of Research in Interactive Marketing, 9(1), 31-53. doi: http://doi.org/10.1108/JRIM-02-2014-0007

Schivinski, B., \& Dabrowski, D. (2016). The effect of social media communication on consumer perceptions of brands. Journal of Marketing Communications, 22(2), 189-214. doi: http://doi.org/10.1080/13527266.2013. 871323

Shao, G. (2009). Understanding the appeal of usergenerated media: A uses and gratification perspective. Internet Research, 19(1), 7-25. doi: http://doi.org/ $10.1108 / 10662240910927795$
Shimp, T. A., \& Kavas, A. (1984). The Theory of Reasoned Action applied to coupon usage. Journal of Consumer Research, 11(3), 795-809. doi: http://doi. org/10.1086/209015

Simonin, B. L., \& Ruth, J. A. (1998). Company known by the spillover keeps? Assessing the of effects. Journal of Marketing Research, 35(1), 30-42. doi: http://doi. org $/ 10.2307 / 3151928$

Smith, A. N., Fischer, E., \& Yongjian, C. (2012). How does brand-related user-generated content differ across YouTube, Facebook, and Twitter? Journal of Interactive Marketing, 26(2), 102-113. doi: http://doi.org/10.1016/ j.intmar.2012.01.002

Smith, R. E., \& Swinyard, W. R. (1983). Attitude-behavior consistency: The impact of product trial versus advertising. Journal of Marketing Research, 20(3), 257-267. doi: https://www.jstor.org/stable/3151829

Sneath, J. Z., Finney, R. Z., \& Close, A. G. (2005). An IMC approach to event marketing: The effects of sponsorship and experience on customer attitudes. Journal of Advertising Research, 45(4), 373-381. doi: http://doi. org/10.1017/S0021849905050440

socialbakers. (2017). Facebook statistics directory. Retrieved from https://www.socialbakers.com/statistics/ facebook/

Spears, N., \& Singh, S. N. (2004). Measuring attitude toward the brand and purchase intentions. Journal of Current Issues and Research in Advertising, 26(2), 53-66. doi: http://doi.org/10.1080/10641734.2004.10505164

Statista. (2017a). Global sponsorship spending from 2007 to 2018 (in billion of U.S. dollars). Retrieved from https:// www.statista.com/statistics/196864/global-sponsorshipspending-since-2007/

Statista. (2017b). Social media usage in the United Kingdom (UK)-Statistics \& facts. Retrieved from https:// www.statista.com/topics/3236/social-media-usage-inthe-uk/

Till, B. D., \& Nowak, L. I. (2000). Toward effective use of cause-related marketing alliances. Journal of Product \& Brand Management, 9(7), 472-484. doi: http://doi. org/10.1108/10610420010351394

Turri, A. M., \& Smith, K. H. (2013). Developing affective brand commitment through social media. Journal of Electronic Commerce Research, 14(3), 201-215.

van Doorn, J., Lemon, K. N., Mittal, V., Nass, S., Pick, D., Pirner, P., \& Verhoef, P. C. (2010). Customer engagement behavior: Theoretical foundations and research directions. Journal of Service Research, 13(3), 253-266. doi: http://doi.org/10.1177/109467051037 5599

Vanden Bergh, B. G., Lee, M., Quilliam, E. T., \& Hove, T. (2011). The multidimensional nature and brand impact of user-generated ad parodies in social media. International Journal of Advertising, 30(1), 103-131. doi: http:// doi.org/10.2501/IJA-30-1-103-131

Villarejo-Ramos, A. F., \& Sánchez-Franco, M. J. (2005). The impact of marketing communication and price promotion on brand equity. Journal of Brand Management, 
12(6), 431-444. doi: http://doi.org/10.1057/palgrave. bm. 2540238

Vivek, S. D., Beatty, S. E., Dalela, V., \& Morgan, R. M. (2014). A generalized multidimensional scale for measuring customer engagement. The Journal of Marketing Theory and Practice, 22(4), 401-420. doi: http://doi. org/10.2753/MTP1069-6679220404

Vivek, S. D., Beatty, S. E., \& Morgan, R. M. (2012). Customer engagement: Exploring customer relationships beyond purchase. Journal of Marketing Theory and Practice, 20(2), 127-145. doi: http://doi.org/10.2753/ MTP1069-6679200201

Wallace, E., Buil, I., \& Chernatony, L. De. (2014). Consumer engagement with self-expressive brands: brand love and WOM outcomes. Journal of Product \& Brand Management, 23(1), 33-42. doi: http://doi.org/10.1108/ JPBM-06-2013-0326

Witkemper, C., Lim, C. H., \& Waldburger, A. (2012). Social media and sports marketing: Examining the motivations and constraints of Twitter users. Sport Marketing Quarterly, 21(3), 170-183.
Wohlfeil, U., \& Whelan, S. (2006). Consumer motivations to participate in event-marketing strategies. Journal of Marketing Management, 22, 643-669.

Wood, E. H. (2009). Evaluating event marketing: Experience or outcome? Journal of Promotion Management, 15(1-2), 247-268. doi: http://doi.org/10.1080/ 10496490902892580

Xiang, Z., \& Gretzel, U. (2010). Role of social media in online travel information search. Tourism Management, 31(2), 179-188. doi: http://doi.org/10.1016/j.tourman. 2009.02.016

Zarantonello, L., \& Schmitt, B. H. (2013). The impact of event marketing on brand equity: The mediating roles of brand experience and brand attitude. International Journal of Advertising, 32(2), 255-280. doi: https://doi. org/10.2501/IJA-32-2-255-280

Zhang, J., Sung, Y., \& Lee, W. (2010). To play or not to play: An exploratory content analysis of branded entertainment in Facebook. American Journal of Business, 25(1), 53-65. doi: http://doi.org/https://doi.org/ $10.1108 / 19355181201000005$ 
